\title{
PENERAPAN AKUNTANSI MANAJEMEN LINGKUNGAN TERHADAP KINERJA KEUANGAN: KINERJA LINGKUNGAN SEBAGAI PEMEDIASI
}

\author{
ROFI DINNILAH AFAZIS \\ SUSI HANDAYANI \\ Jurusan Akuntansi, Fakultas Ekonomi, Universitas Negeri Surabaya, Jl. Ketintang No. 2, Ketintang, Kec. \\ Gayungan, Kota Surabaya, Indonesia \\ rofiafazis16080694047@mhs.unesa.ac.id
}

\begin{abstract}
This study aims to examine the mediating effect of environmental performance on the link between environmental management accounting and financial performance. The research sample is 29 companies listed in Indonesia Stock Exchange for the period 2017-2018. The data analysis technique used are path analysis and sobel test with Statistical Package for Social Sciences (SPSS) 22 programs. The result of this research show that the application of environmental management accounting has no effect on environmental performance and environmental performance has no effect on financial performance, so it can be conclude that environmental performance cannot mediate the relationship between environmental management accounting and financial performance.
\end{abstract}

Keywords: Environmental management accounting, environmental performance, financial performance, nonfinancial company

Abstrak: Penelitian ini bertujuan untuk menguji pengaruh mediasi kinerja lingkungan pada hubungan antara akuntansi manajemen lingkungan dengan kinerja keuangan. Sampel yang digunakan dalam penelitian ini adalah 29 perusahaan yang terdaftar di Bursa Efek Indonesia periode 2017-2018. Teknik analisis data yang digunakan adalah analisis jalur dan uji sobel dengan bantuan program Statistical Package for Social Sciences (SPSS) 22. Hasil penelitian ini menunjukkan bahwa penerapan akuntansi manajemen lingkungan tidak mempengaruhi kinerja lingkungan dan kinerja lingkungan tidak mempengaruhi kinerja keuangan, sehingga dapat disimpulkan bahwa kinerja lingkungan tidak dapat memediasi hubungan antara akuntansi manajemen lingkungan dengan kinerja keuangan.

Kata kunci: Akuntansi manajemen lingkungan, kinerja lingkungan, kinerja keuangan, perusahaan non-keuangan

\section{PENDAHULUAN}

Indonesia merupakan negara berkembang dengan jumlah populasi penduduk paling banyak keempat di dunia. Dikutip dari Worldometers.info, Indonesia memiliki populasi penduduk sebanyak 273 juta jiwa. Penduduk Indonesia akan terus mengalami pertumbuhan setiap tahunnya. Pertumbuhan penduduk akan mendorong laju pertumbuhan PDB (Produk Domestik Bruto) guna memenuhi permintaan konsumen dan semakin beragamnya pola konsumsi masyarakat.

Pertumbuhan PDB ternyata dapat menyebabkan semakin banyaknya volume, jenis, dan karakteristik sampah dan limbah 
(Badan Pusat Statistik 2018). Berdasarkan informasi INAPLAS dan BPS, Indonesia menghasilkan setidaknya 64 juta ton sampah plastik setiap tahunnya, dimana 3,2 juta ton diantaranya dibuang ke laut (Sofuroh 2019). Hal tersebut akan berimbas pada kondisi laut di Indonesia. Peneliti dari University of Georgia, Jenna R. Jambeck, juga membenarkan bahwa Indonesia menduduki posisi kedua sebagai negara yang paling banyak membuang sampah plastik ke laut (Adharsyah 2019). Indonesia bahkan jauh lebih buruk dibanding India yang menduduki peringkat ke-12 dengan tingkat pencemaran sekitar 0,09-0,24 juta ton pertahun, padahal jumlah penduduk pesisir India serupa dengan Indonesia, yakni sebesar 187 juta jiwa. $\mathrm{Hal}$ ini mengindikasikan bahwa sistem pengelolaan sampah di Indonesia masih buruk.

Pemerintah telah berupaya untuk menangani masalah sampah dan limbah di Indonesia. Upaya pemerintah untuk mengurangi timbulan sampah dan limbah salah satunya dilakukan dengan mengadakan Program Penilaian Peringkat Kinerja Perusahaan (PROPER) melalui Menteri Lingkungan Hidup, yang mengacu pada Permen LH No. 03 Tahun 2014. Langkah ini bertujuan untuk mendorong perusahaan dan industri agar lebih peduli terhadap isu-isu lingkungan dalam menjalankan aktivitas bisnisnya dan ikut berkontribusi dalam menjaga lingkungan sekitar agar tetap lestari, serta mengurangi timbulan sampah dan limbah di Indonesia.

Pelaksanaan PROPER dimulai dengan pemilihan peserta. Perusahaan peserta PROPER dipilih berdasarkan kriteria tertentu, diantaranya memiliki dampak terhadap lingkungan, mencatatkan sahamnya di bursa, dan produk yang dihasilkan bertujuan untuk diekspor atau bermanfaat bagi masyarakat luas. Berdasarkan hasil penilaian PROPER periode 2017-2018, hanya terdapat 59 perusahaan peserta PROPER yang tercatat di bursa (Menteri Lingkungan Hidup dan Kehutanan Republik Indonesia, 2018). Dari total keseluruhan peserta PROPER yang tercatat di bursa, hanya sektor keuangan (finance) saja yang tidak masuk dalam kategori peserta. Hal ini dikarenakan perusahaan pada sektor keuangan dalam menjalankan aktivitas bisnisnya tidak berkaitan dengan lingkungan dan dampak lingkungan yang dihasilkannya lebih kecil dibanding sektor usaha lainnya.

Hasil penilaian PROPER periode 20172018 pada 1.906 perusahaan menunjukkan tingkat ketaatan sebesar $87 \%$ dan mampu menghasilkan penghematan dari upaya efisiensi air dan energi, serta menurunkan emisi konvensional dan emisi GRK (Gas Rumah Kaca) (Herdiyan 2018). Upaya lainnya yang berhasil dicapai berupa penurunan dan pemanfaatan limbah B3 dan limbah padat nonB3 serta penurunan beban pencemaran air limbah. Program tersebut ternyata mampu meningkatkan ketaatan perusahaan terhadap peraturan lingkungan dari tahun ke tahun. Hal ini mengindikasikan bahwa perusahaan dan industri di Indonesia tetap memperhatikan isuisu lingkungan dalam menjalankan kegiatan operasionalnya.

Pengelolaan dampak lingkungan yang dilakukan perusahaan, selain untuk mematuhi peraturan pemerintah, upaya tersebut juga dilakukan sebagai wujud pemenuhan kewajiban perusahaan kepada masyarakat. Hal ini terkait dengan legitimacy theory, yang menjelaskan bahwa suatu perusahaan harus mematuhi kontrak dan norma yang berlaku di masyarakat dalam menjalankan aktivitas bisnisnya, (Fernando and Lawrence 2014). Pengelolaan sampah dan limbah yang dilakukan perusahaan akan menciptakan kualitas lingkungan hidup yang lebih baik, sehingga keberadaan perusahaan dapat diterima dengan baik oleh masyarakat. Hal ini menunjukkan bahwa aktivitas yang dijalankan perusahaan tidak hanya terfokus untuk memperoleh keuntungan semata, tetapi juga turut berkontribusi dalam menjaga kelestarian alam, sehingga perusahaan mampu memenuhi semua 
kepentingan stakeholder-nya (internal dan eksternal stakeholder). Hal ini berkaitan dengan stakeholder theory, yang menjelaskan bahwa sebuah perusahaan berdiri untuk memenuhi semua kepentingan stakeholder perusahaan, bukan hanya pemilik modal (shareholder) (Sawitri 2017).

Pengelolaan dampak lingkungan dapat dilakukan melalui penerapan akuntansi manajemen lingkungan (AML). Menurut Wang et al. (2019) akuntansi manajemen lingkungan merupakan langkah yang efektif untuk membantu perusahaan dalam menangani masalah lingkungan. Melalui penerapan AML, perusahaan dapat mencapai kinerja lingkungan yang baik. Hal ini sesuai dengan penelitian Phan et al. (2017), Solovida and Latan (2017), dan Latan et al. (2018). Solovida and Latan (2017) menjelaskan bahwa frekuensi penerapan AML akan berimbas pada kinerja lingkungan yang dihasilkan perusahaan. Semakin besar frekuensi penerapan AML, maka kinerja lingkungan yang dihasilkan akan semakin baik. Melalui penerapan AML, manajer perusahaan akan termotivasi untuk lebih memperhatikan isuisu lingkungan dalam pengambilan keputusan berdasarkan informasi yang dihasilkan, sehingga pengambilan keputusan oleh manajemen dapat berupa tindakan yang dapat membantu perusahaan menghasilkan kinerja lingkungan yang diinginkan (Phan et al. 2017).

Kinerja lingkungan berkaitan dengan hasil yang didapat perusahaan dari kegiatan pengelolaan dampak lingkungan (ISO 14031 2013). Kinerja lingkungan yang baik akan meningkatkan kepercayaan masyarakat dan konsumen. Dalam jangka panjang, kepercayaan stakeholder perusahaan dapat meningkatkan pendapatan perusahaan (Supadi dan Sudana 2018). Peningkatan kinerja lingkungan melalui penerapan akuntansi manajemen lingkungan juga dapat menjadikan perusahaan lebih efisien dalam mengelola biaya lingkungan. Efisiensi biaya akan membantu perusahaan memperoleh laba yang lebih tinggi dibandingkan apabila tidak ada efisiensi (Hidayat dan Salim 2013). Semakin baik kinerja lingkungan yang dihasilkan, maka kinerja keuangan yang diperoleh perusahaan juga akan semakin baik (Andayani 2015, Putra dan Utami 2017, Supadi dan Sudana 2018). Berdasarkan penjelasan tersebut, dapat diketahui bahwa kinerja lingkungan dapat memediasi akuntansi manajemen lingkungan dengan kinerja keuangan. Penelitian terkait ketiga variabel tersebut sudah pernah dilakukan oleh Henri and Journeault (2010) dan Rahmadhani dan Meylani (2016).

Henri and Journeault (2010) menyatakan bahwa kinerja lingkungan dapat menjadi mediator hubungan antara eco-control dengan kinerja ekonomi perusahaan. Rahmadhani dan Meylani (2016) justru menemukan bahwa kinerja lingkungan tidak dapat menjadi mediator antara eco-control dengan kinerja keuangan. Hasil penelitian tersebut menunjukkan bahwa eco-control dapat meningkatkan kinerja lingkungan, tetapi kinerja lingkungan tidak mempengaruhi kinerja keuangan.

Perbedaan hasil penelitian dari penelitipeneliti terdahulu memotivasi penulis untuk meneliti kembali peran mediasi kinerja lingkungan pada hubungan antara akuntansi manajemen lingkungan dengan kinerja keuangan. Penelitian ini juga dimaksudkan untuk menambah referensi terkait akuntansi manajemen lingkungan yang masih belum banyak dibahas di Indonesia, mengingat akuntansi manajemen lingkungan memiliki konsep yang sangat komplek yang dapat membantu manajemen menghasilkan keputusan terkait pengelolaan dampak lingkungan.

\section{Stakeholder Theory}

Freeman et al. (2010: 26) mendefinisikan stakeholder sebagai sekelompok orang atau individu yang mempengaruhi bisnis perusahaan, sehingga perusahaan akan berupaya menciptakan nilai bagi pihak-pihak tersebut agar bisnis perusahaan dapat terus hidup. Stakeholder 
perusahaan terbagi menjadi primary dan secondary stakeholder (Freeman et al. 2007: 10). Primary stakeholder merupakan pihakpihak yang keberadaannya sangat vital bagi keberlanjutan bisnis perusahaan, sedangkan secondary stakeholder hanya memiliki kepentingan yang bersifat sukarela dengan perusahaan. Menurut Sawitri (2017) stakeholder theory menjelaskan bahwa sebuah perusahaan berdiri untuk memenuhi semua kepentingan stakeholder-nya, bukan hanya pemilik modal (shareholder).

\section{Legitimacy Theory}

Legitimacy theory menekankan bahwa suatu perusahaan harus mematuhi kontrak dan norma yang berlaku di masyarakat dalam menjalankan aktivitas bisnisnya (Fernando and Lawrence 2014). Teori ini didasari karena adanya kontrak sosial antara perusahaan dengan masyarakat sekitar (Ghozali dan Chariri 2014: 442). Melalui kontrak sosial tersebut, aktivitas bisnis yang dijalankan perusahaan harus disamakan dan disesuaikan dengan persepsi masyarakat sekitar, agar keberadaan perusahaan dapat diterima ditengah-tengah masyarakat. Menurut Fernando and Lawrence (2014) perusahaan akan melakukan apapun yang mungkin untuk melegitimasi bisnisnya dan memastikan kelangsungan hidup perusahaan.

\section{Akuntansi Manajemen Lingkungan}

International Federation of Accountants

(2005) mendefinisikan akuntansi manajemen lingkungan (AML) sebagai upaya perusahaan dalam mengelola kinerja lingkungan dan keuangan, dengan menerapkan suatu sistem akuntansi lingkungan yang sesuai dengan kondisi perusahaan. Penerapan AML dapat membantu manajer perusahaan dalam pengambilan keputusan, yaitu melalui proses identifikasi, pengumpulan data, dan analisis menggunakan dua jenis informasi (fisik dan moneter). Informasi fisik berupa informasi terkait jumlah pemakaian air, energi, dan bahan baku, serta jumlah limbah dan emisi yang dilepaskan ke luar (lingkungan). Informasi moneter berupa biaya lingkungan, pendapatan, dan penghematan yang dihasilkan dari penerapan AML.

Burritt and Saka (2006) menjelaskan bahwa akuntansi manajemen lingkungan merupakan alat baru dalam pengelolaan lingkungan yang semula didesain untuk mencari dan menelusuri biaya-biaya lingkungan dan aliran lingkungan fisik, yang pada akhirnya dapat membantu manajemen untuk menghasilkan keputusan bisnis yang lebih baik. Akuntansi manajemen lingkungan memberikan kontribusi pada kelangsungan usaha atau bisnis perusahaan dalam jangka panjang, dimana akuntansi manajemen lingkungan dapat menjadi alat baru bagi manajer perusahaan dalam meningkatkan laba dan kinerja lingkungan perusahaan (Sambharakreshna 2009). Berdasarkan penjelasan tersebut, akuntansi manajemen lingkungan dapat didefinisikan sebagai alat yang efektif untuk mengurangi biaya dan memaksimalkan laba perusahaan, serta meminimalkan dampak lingkungan yang dihasilkan dari aktivitas perusahaan (Xiaomei 2004).

\section{Kinerja Lingkungan}

Menurut ISO 14031 (2013) kinerja lingkungan didefinisikan sebagai hasil terukur yang didapat dari kegiatan pengelolaan lingkungan yang dijalankan perusahaan. Kinerja lingkungan juga didefinisikan sebagai dampak lingkungan berbahaya yang dihasilkan dari kegiatan operasional perusahaan (Lankoski 2000). Semakin sedikit dampak lingkungan berbahaya yang dihasilkan, maka kinerja lingkungan yang dicapai perusahaan semakin baik. Berdasarkan uraian tersebut, maka kinerja lingkungan dapat didefinisikan sebagai hasil dari aktivitas perusahaan yang berhubungan dengan aspek lingkungan, baik buruknya kinerja lingkungan yang dicapai perusahaan 
bergantung pada besar kecilnya dampak lingkungan berbahaya yang dihasilkan.

\section{Kinerja Keuangan}

Kinerja keuangan didefinisikan sebagai suatu ukuran tertentu yang digunakan untuk menilai keberhasilan suatu perusahaan dalam memperoleh keuntungan (Bahri dan Cahyani 2016). Menurut Wulandari dan Hidayah (2013) kinerja keuangan diperlukan untuk mengukur kondisi keuangan (financial health) suatu perusahaan. Pengukuran kinerja keuangan dapat dilakukan menggunakan data-data dan informasi dalam laporan keuangan dan tahunan yang dipublikasikan perusahaan setiap tahunnya. Terdapat dua pendekatan yang dapat digunakan untuk mengukur kinerja keuangan perusahaan, yaitu pendekatan pasar (marketbased measures) dan pendekatan akuntansi (accounting-based measures) (Al-Tuwaijri et al. 2003).

\section{Akuntansi Manajemen Lingkungan dan Kinerja Lingkungan}

Penerapan AML secara efektif dapat membantu perusahaan dalam menangani masalah lingkungan (Wang et al. 2019). Penerapan AML dapat membantu manajemen perusahaan menyediakan informasi fisik dan moneter. Informasi tersebut dapat meningkatkan kesadaran manajemen terhadap isu-isu lingkungan dan merespon tekanan dari pihak eksternal (secondary stakeholder) seperti masyarakat sekitar dimana perusahaan beroperasi (Phan et al. 2017), sehingga manajemen dapat menghasilkan keputusan bisnis terkait pengelolaan dampak lingkungan untuk meningkatkan kinerja lingkungan. Solovida and Latan (2017) menjelaskan bahwa frekuensi penerapan AML akan berimbas pada kinerja lingkungan yang dihasilkan perusahaan. Perusahaan yang menginginkan kinerja lingkungan yang baik perlu memperbesar frekuensi penerapan AML yang dijalankannya. Berdasarkan penjelasan tersebut, maka penerapan $\mathrm{AML}$ dapat meningkatkan kinerja lingkungan yang dihasilkan perusahaan (Solovida and Latan 2017, Phan et al. 2017, Latan et al. 2018), sehingga hipotesis dalam penelitian ini dirumuskan sebagai berikut.

$\mathrm{H}_{1}$ Penerapan akuntansi manajemen lingkungan berpengaruh positif terhadap kinerja lingkungan

\section{Kinerja Lingkungan dan Kinerja Keuangan}

Menurut Andayani (2015) perusahaan yang memperhatikan tanggung jawab terhadap lingkungan akan memperoleh respon positif dari investor, baik shareholder perusahaan maupun calon investor. Kepercayaan investor dapat mendorong meningkatnya return atau pengembalian atas investasi perusahaan. Selain kepercayaan investor, perusahaan juga akan mendapat kepercayaan masyarakat dengan menghasilkan kinerja lingkungan yang baik (Putra dan Utami 2017). Hal tersebut dapat meningkatkan pendapatan perusahaan dalam jangka panjang (Supadi dan Sudana 2018). Berdasarkan uraian tersebut, maka peningkatan kinerja keuangan perusahaan dapat dicapai apabila perusahaan mampu menghasilkan kinerja lingkungan yang baik (Andayani 2015, Putra dan Utami 2017, Supadi dan Sudana 2018), sehingga hipotesis dalam penelitian ini dirumuskan sebagai berikut.

$\mathrm{H}_{2}$ Kinerja lingkungan berpengaruh positif terhadap kinerja keuangan

\section{Akuntansi Manajemen Lingkungan, Kinerja Lingkungan, dan Kinerja Keuangan}

Penerapan AML akan membantu manajemen menghasilkan keputusan bisnis yang lebik baik dengan tetap memperhatikan isu-isu lingkungan, sehingga perusahaan mampu menghasilkan kinerja lingkungan yang diinginkan. Kinerja lingkungan yang dihasilkan akan memperoleh respon positif dari stakeholder perusahaan, seperti meningkatnya pengembalian atas investasi perusahaan karena meningkatnya kepercayaan investor dan meningkatnya pendapatan perusahaan dalam jangka panjang karena kepercayaan masyarakat terhadap kegiatan operasional yang 
dijalankan perusahaan. Penjelasan tersebut menunjukkan bahwa penerapan AML akan meningkatkan kinerja lingkungan dan kinerja lingkungan yang baik juga akan berimbas pada peningkatan kinerja keuangan perusahaan. Hal ini berarti kinerja lingkungan dapat memediasi akuntansi manajemen lingkungan dengan kinerja keuangan perusahaan (Henri and Journeault 2010), sehingga hipotesis dalam penelitian ini dirumuskan sebagai berikut.

$\mathrm{H}_{3}$ Penerapan akuntansi manajemen lingkungan berpengaruh positif terhadap kinerja keuangan perusahaan melalui kinerja lingkungan.

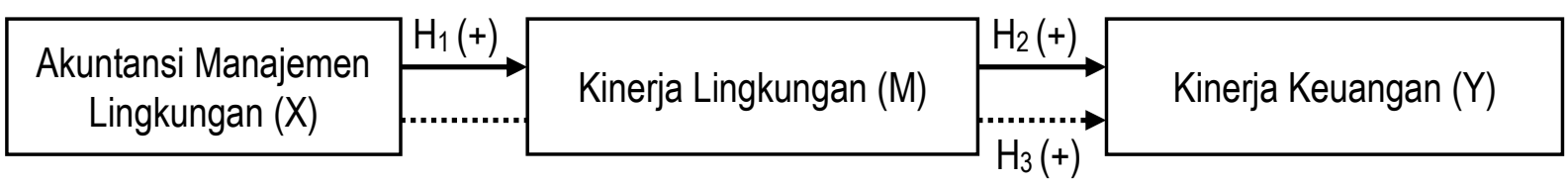

Gambar 1 Model Penelitian

\section{METODE PENELITIAN}

Sampel penelitian ini adalah perusahaan yang terdaftar di BEI periode 20172018 selain sektor finance. Sektor finance tidak dikategorikan menjadi sampel penelitian karena penelitian ini terkait lingkungan dan berdasarkan data PROPER 2017-2018, perusahaan sektor finance tidak termasuk dalam kategori peserta. Pemilihan sampel menggunakan teknik purposive sampling dengan kriteria berikut:

a. Perusahaan di BEl selain sektor finance yang menyajikan laporan tahunan dan keberlanjutan secara lengkap dari tahun 2017-2018.

b. Perusahaan yang menyajikan laporan keberlanjutan dengan berpedoman pada GRI Standar 2016.

Jenis data penelitian adalah data sekunder yakni laporan tahunan dan keberlanjutan perusahaan yang dapat diunduh pada situs resmi Indonesia Stock Exchange (www.idx.co.id) atau situs resmi perusahaan terkait. Terdapat 29 perusahaan yang memenuhi kriteria sampel. Perusahaan sampel yang dimaksud disajikan dalam tabel berikut:

Tabel 1 Daftar Sampel Penelitian

\begin{tabular}{|c|c|c|c|c|c|}
\hline No. & Kode & Nama Perusahaan & No. & Kode & Nama Perusahaan \\
\hline 1. & ANJT & Austindo Nusantara Jaya & 16. & INCO & Vale Indonesia \\
\hline 2. & BWPT & Eagle High Plantations & 17. & ITMG & Indo Tambangraya Megah \\
\hline 3. & LSIP & PP London Sumatra Indonesia & 18. & MEDC & Medco Energi International \\
\hline 4. & SIMP & Salim Ivomas Pratama & 19. & ASII & Astra International \\
\hline 5. & INTP & Indocement Tunggal Prakarsa & 20. & GMFI & $\begin{array}{l}\text { Garuda Maintenance Facility } \\
\text { Aero Asia }\end{array}$ \\
\hline 6. & SMCB & Solusi Bangun Indonesia & 21. & $\mathrm{ADHI}$ & Adhi Karya (Persero) \\
\hline 7. & SMGR & Semen Indonesia (Persero) & 22. & PPRO & PP Properti \\
\hline 8. & WTON & Wijaya Karya Beton & 23. & PTPP & PP (Persero) \\
\hline 9. & KLBF & Kalbe Farma & 24. & WIKA & Wijaya Karya (Persero) \\
\hline 10. & MLBI & Multi Bintang Indonesia & 25. & WSKT & Waskita Karya (Persero) \\
\hline 11. & UNVR & Unilever Indonesia & 26. & ABMM & ABM Investama \\
\hline 12. & JSMR & Jasa Marga (Persero) & 27. & AKRA & AKR Corporindo \\
\hline 13. & PGAS & Perusahaan Gas Negara & 28. & BNBR & Bakrie \& Brothers \\
\hline 14. & ANTM & Aneka Tambang & 29. & PJAA & Pembangunan Jaya Ancol \\
\hline 15. & ELSA & Elnusa & & & \\
\hline
\end{tabular}


Akuntansi manajemen lingkungan didefinisikan sebagai upaya perusahaan dalam mengelola kinerja lingkungan dan keuangan, dengan menerapkan suatu sistem akuntansi lingkungan yang sesuai dengan kondisi perusahaan. Penerapan akuntansi manajemen lingkungan direpresentasikan oleh sertifikat ISO 14001 yang diperoleh perusahaan.

Kinerja keuangan didefiniskan sebagai suatu ukuran tertentu yang digunakan untuk menilai keberhasilan suatu perusahaan dalam memperoleh keuntungan. Pengukuran kinerja keuangan menggunakan market-based measures (Tobin's Q), karena dapat merepresentasikan kinerja perusahaan selama periode berjalan dan di masa mendatang (Miroshnychenko et al. 2017). Nilai yang dihasilkan dari perhitungan rasio Tobin's $Q$ merupakan nilai perusahaan di mata investor. Perusahaan dikatakan mampu menciptakan nilai, apabila rasio Tobin's $Q>1$. Nilai tersebut mengindikasikan bahwa perusahaan dinilai lebih tinggi di pasar dibanding nilai aset perusahaan sebenarnya. Berikut ini cara menghitung rasio Tobin's Q:

$$
\text { Tobin's } Q=\frac{M V+B V L}{B V A}
$$

Keterangan:

$$
\begin{array}{ll}
\text { MV } & =\text { Kapitalisasi Pasar } \\
B V D & =\text { Nilai Buku Liabilitas } \\
B V A & =\text { Nilai Buku Aset }
\end{array}
$$

Kinerja lingkungan merupakan hasil dari aktivitas perusahaan yang berhubungan dengan aspek lingkungan, baik buruknya kinerja lingkungan yang dicapai perusahaan bergantung pada besar kecilnya dampak lingkungan berbahaya yang dihasilkan. Pengukuran kinerja lingkungan menggunakan indeks GRI yang berpedoman pada GRI Standar 2016. Perhitungan indeks GRI dilakukan dengan cara sebagai berikut:

$$
\text { Indeks GRI }=\frac{\text { Jumlah item yang diungkapkan }}{\text { Jumlah item }}
$$

Teknik analisis data yang digunakan berupa analisis jalur dan uji sobel dengan bantuan program Statistical Package for Social Sciences (SPSS) 22. Berikut persamaan regresi yang digunakan untuk analisis jalur:

$$
\begin{aligned}
& E P=\propto+\beta_{2} A M L+\varepsilon_{2} \ldots \ldots \ldots \ldots \\
& F P=\propto+\beta_{1} A M L+\beta_{3} E P+\varepsilon_{1}
\end{aligned}
$$

$\mathrm{H}_{1}$ dan $\mathrm{H}_{2}$ diterima apabila nilai sig. $\mathrm{t}$ kurang dari derajat kepercayaan $(\alpha)$ sebesar 0,05 dan koefisien regresi $(\beta)$ menunjukkan nilai positif. $\mathrm{H}_{3}$ diterima apabila hasil uji sobel atau nilai t pengaruh tidak langsung > nilai t tabel. 


\section{HASIL PENELITIAN}

Hasil uji statistik deskriptif dan hipotesis dapat dilihat pada tabel berikut:

Tabel 2 Hasil Uji Statistik Deskriptif

\begin{tabular}{lcccc}
\hline \multicolumn{1}{c}{ Keterangan } & Min. & Max. & Mean & Std. Deviasi \\
\hline Akuntansi Manajemen Lingkungan & 0 & 1 & 0,71 & 0,46 \\
Kinerja Keuangan & 0,67 & 23,29 & 2,38 & 4,13 \\
Kinerja Lingkungan & 0,03 & 0,63 & 0,27 & 0,14 \\
\hline
\end{tabular}

Tabel 3 Hasil Uji Hipotesis

\begin{tabular}{lcccccc}
\hline & \multicolumn{3}{c}{ EP } & \multicolumn{3}{c}{ FP } \\
\cline { 2 - 7 } & $\boldsymbol{\beta}$ & Std. Error & Sig. & $\boldsymbol{\beta}$ & Std. Error & Sig. \\
\hline $\boldsymbol{\alpha}$ & 0,825 & 0,014 & 0,000 & 1,019 & 0,037 & 0,000 \\
AML & 0,017 & 0,016 & 0,315 & $-0,015$ & 0,018 & 0,451 \\
EP & & & & 0,015 & 0,060 & 0,798 \\
\hline
\end{tabular}

Nilai sig. $t$ variabel akuntansi manajemen lingkungan terhadap kinerja lingkungan sebesar $0,315>0,05$. Nilai tersebut mengindikasikan bahwa penerapan AML tidak berpengaruh terhadap kinerja lingkungan, yang berarti bahwa $\mathrm{H}_{1}$ ditolak. Akuntansi manajemen lingkungan merupakan alat baru yang efektif digunakan untuk mengatasi masalah lingkungan. Melalui penerapan AML perusahaan dapat menghasilkan dua jenis informasi (fisik dan moneter). Informasi tersebut selanjutnya akan diidentifikasi, dikumpulkan, dan dianalisis oleh pihak manajemen untuk menghasilkan keputusan bisnis dengan tetap memperhatikan isu-isu lingkungan. Keputusan bisnis yang diambil manajemen dapat berkaitan dengan pengelolaan dampak lingkungan yang dihasilkan perusahaan. Penerapan AML diharapkan dapat menjadi solusi yang tepat bagi perusahaan untuk mencapai kinerja lingkungan yang lebih baik.

Hal ini ternyata berbeda dengan yang terjadi pada perusahaan sampel. Perusahaan yang telah mengimplementasikan akuntansi manajemen lingkungan atau telah memperoleh sertifikat ISO 14001 berturut-turut dari tahun 2017-2018 justru menghasilkan kinerja lingkungan yang buruk (indeks GRI di bawah rata-rata). Dari 29 perusahaan sampel, terdapat 19 perusahaan yang sudah menerapkan akuntansi manajemen lingkungan selama dua tahun berturut-turut. Berdasarkan analisis data dapat diketahui bahwa sebesar $63 \%$ perusahaan atau sebanyak 12 dari 19 perusahaan memiliki kinerja lingkungan yang buruk. Perusahaan tersebut diantaranya adalah PT Adhi Karya Tbk., PT Bakrie \& Brothers Tbk., PT Elnusa Tbk., PT Garuda Maintenance Facility Aero Asia Tbk., PT Indo Tambangraya Megah Tbk., PT Kalbe Farma Tbk., PT Perusahaan Gas Negara Tbk., PT PP Tbk., PT Semen Indonesia Tbk., PT Unilever Indonesia Tbk., PT Waskita Karya Tbk., dan PT Wijaya Karya Tbk. Perusahaan dengan indeks GRI paling tinggi atau memiliki kinerja lingkungan yang paling baik diperoleh oleh PT Solusi Bangun Indonesia Tbk., dimana perusahaan tersebut baru menerapkan akuntansi manajemen lingkungan di tahun 2018. Berdasarkan data-data tersebut, maka penerapan $A M L$ pada perusahaan sampel tidak berpengaruh terhadap kinerja lingkungan yang dihasilkan perusahaan. 
Keterlibatan manajemen menjadi kunci keberhasilan perusahaan dalam menghasilkan kinerja lingkungan yang baik, melalui penerapan sebuah alat atau sistem yang disebut akuntansi manajemen lingkungan. Manajemen merupakan pihak yang mengolah informasi yang dihasilkan menjadi sebuah keputusan bisnis seperti strategi yang harus dijalankan perusahaan kedepannya agar pengelolaan dampak lingkungan dapat dijalankan dengan baik dan mampu menghasilkan kinerja lingkungan yang baik pada akhirnya. Semakin banyak informasi yang dihasilkan, maka akan semakin kompleks perencanaan yang dapat dibuat oleh pihak manajemen.

Pada perusahaan sampel, informasi terkait lingkungan yang dihasilkan masih sedikit. Informasi yang paling banyak dihasilkan adalah informasi terkait jumlah penggunaan energi dan air, pengurangan energi, limbah yang dihasilkan, dan kepatuhan terhadap peraturan yang ada. Informasi terkait lingkungan lainnya masih banyak yang belum dilaporkan. Minimnya informasi yang disajikan akan berdampak pada keputusan bisnis yang dihasilkan manajemen, karena manajemen hanya mempunyai sedikit informasi untuk dijadikan dasar dalam membuat kebijakan terkait pengelolaan lingkungan. Informasi yang dihasilkan juga akan berdampak pada besarnya indeks GRI yang diperoleh perusahaan. Diketahui bahwa 19 dari 29 perusahaan sampel telah menerapkan akuntansi manajemen lingkungan (memiliki sertifikat ISO 14001), namun 12 diantaranya justru memiliki kinerja lingkungan yang buruk. Hal ini dikarenakan minimnya informasi yang dihasilkan perusahaan, sehingga indeks GRI yang diperoleh kecil dan kinerja lingkungannya dinilai buruk. Hal tersebut mengakibatkan hasil penelitian ini inkonsisten dengan penelitian Phan et al. (2017), Solovida and Latan (2017), dan Latan et al. (2018), karena menghasilkan hubungan yang tidak berpengaruh. Hasil penelitian juga tidak mendukung legitimacy theory, karena upaya perusahaan berupa penerapan AML ternyata tidak menjanjikan kinerja lingkungan yang baik. Perusahaan yang menerapkan akuntansi manajemen lingkungan belum tentu dapat menghasilkan kinerja lingkungan yang baik, yang dapat membantu perusahaan melegitimasi bisnisnya di tengahtengah masyarakat.

Nilai sig. $t$ variabel kinerja lingkungan terhadap kinerja keuangan sebesar 0,798 >0,05 yang berarti bahwa $\mathrm{H}_{2}$ ditolak, karena kinerja keuangan tidak dipengaruhi oleh kinerja lingkungan yang dihasilkan perusahaan. Hal tersebut dapat dikarenakan adanya faktor lain, selain kinerja lingkungan, yang memberikan pengaruh lebih besar terhadap kinerja keuangan. Hasil analisis data menghasilkan bahwa dari 29 perusahaan sampel, hanya delapan perusahaan yang mendapat indeks GRI di atas rata-rata atau menghasilkan kinerja lingkungan yang baik selama dua tahun berturut-turut. Perusahaan tersebut diantaranya PT Aneka Tambang Tbk., PT Astra International Tbk., PT Eagle High Plantations Tbk., PT Multi Bintang Indonesia Tbk., PT PP London Sumatra Indonesia Tbk., PT Salim Ivomas Pratama Tbk., PT Solusi Bangun Indonesia Tbk., dan PT Vale Indonesia Tbk. Dari delapan perusahaan, hanya satu perusahaan yang menghasilkan rasio Tobin's $Q$ di atas rata-rata atau menghasilkan kinerja keuangan yang baik. Hal ini berarti bahwa tujuh perusahaan lainnya menghasilkan kinerja keuangan yang buruk. Perusahaan yang memperoleh kinerja keuangan tertinggi dengan rasio Tobin's $Q$ sebesar 23,29 justru menghasilkan kinerja lingkungan yang buruk, perusahaan tersebut adalah PT Unilever Indonesia Tbk. Data-data tersebut membuktikan bahwa pada perusahaan sampel kinerja keuangan tidak dipengaruhi oleh kinerja lingkungan yang dihasilkannya.

Apabila dikaitkan dengan minat konsumen terhadap pembelian atau penggunaan suatu barang dan jasa, maka kinerja lingkungan tidak akan mempengaruhi kinerja keuangan khususnya pada negara berkembang, seperti Indonesia. Masyarakat Indonesia akan lebih memilih produk dan jasa 
yang low price dibanding produk dan jasa yang ramah lingkungan, namun high price. Hal ini mengindikasikan bahwa konsumen tidak mempertimbangkan kinerja lingkungan yang dihasilkan perusahaan ketika memutuskan untuk membeli dan menggunakan suatu barang dan jasa, sehingga kinerja lingkungan yang dihasilkan perusahaan tidak mampu menaikkan penjualan dan mencetak laba yang lebih tinggi.

Kinerja keuangan juga dapat dipengaruhi faktor lain seperti harga saham dan laba perusahaan. Pengukuran kinerja keuangan dalam penelitian ini menggunakan kinerja pasar, sehingga kinerja keuangan suatu perusahaan sangat ditentukan oleh minat investor terhadap perusahaan. Investor biasanya lebih memperhatikan pencapaian perusahaan pada periode tertentu, seperti besarnya penjualan atau pendapatan dan laba/rugi yang diperoleh perusahaan ketika akan menginvestasikan dana yang dimilikinya. Dalam pengambilan keputusan terkait investasi (jual beli saham), investor dalam pasar modal Indonesia biasanya lebih memperhatikan fluktuasi harga saham atau laba perusahaan dibanding informasi lain seperti kinerja lingkungan yang dihasilkan perusahaan.

Berdasarkan penjelasan tersebut, dapat diketahui bahwa kinerja keuangan tidak dipengaruhi oleh kinerja lingkungan karena adanya faktor-faktor lain, seperti harga produk dan jasa, harga saham, penjualan, dan laba yang dihasilkan perusahaan. Hasil penelitian serupa dengan penelitian Sarumpaet (2005), Wibisono (2011), dan Rohmah dan Wahyudin (2015). Hasil penelitian ini tidak mendukung stakeholder theory, karena kinerja lingkungan yang dihasilkan perusahaan tidak mampu menciptakan nilai bagi stakeholder perusahaan, seperti meningkatkan kinerja keuangan perusahaan.

Analisis jalur dan uji sobel dilakukan untuk menjawab $\mathrm{H}_{3}$. Berikut merupakan analisis jalur yang digunakan dalam penelitian ini:

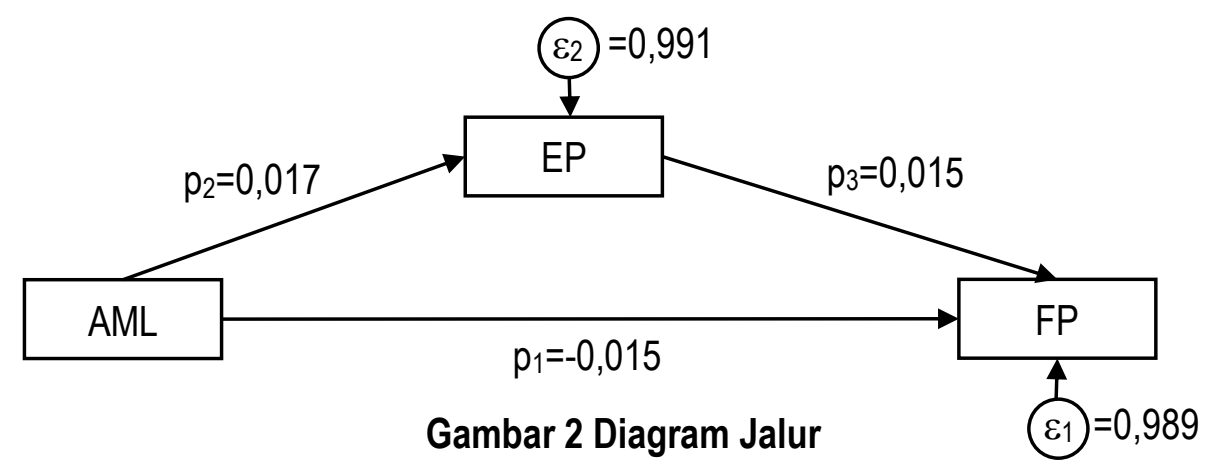

Nilai koefisien jalur merupakan nilai unstandardized beta, besarnya nilai $\varepsilon_{1}=$ $\sqrt{1-0,020}=0,9899$ dan besarnya nilai $\varepsilon_{2}=\sqrt{1-0,018}=0,991$. Berdasarkan $\mathrm{H}_{1}$ dan $\mathrm{H}_{2}$ dapat diketahui bahwa kinerja lingkungan tidak dapat memediasi akuntansi manajemen lingkungan dengan kinerja keuangan. Penerapan akuntansi manajemen lingkungan juga tidak mampu mempengaruhi kinerja keuangan secara langsung, karena nilai sig. sebesar 0,451>0,05. Hal ini berarti bahwa penerapan AML tidak memiliki pengaruh terhadap kinerja keuangan (secara langsung ataupun melalui mediasi kinerja lingkungan). Untuk mengetahui signifkansi pengaruh mediasi, maka perlu dilakukan uji sobel:

$$
\begin{aligned}
& \text { Uji sobel }(t)=\frac{p_{2} \times p_{3}}{\sqrt{\left(p_{2}{ }^{2} S p_{3}{ }^{2}\right)+\left(p_{3}{ }^{2} S p_{2}{ }^{2}\right)+\left(S p_{2}{ }^{2} S p_{3}{ }^{2}\right)}} \\
& =\frac{0,017 \times 0,015}{\sqrt{\left(0,017^{2} 0,060^{2}\right)+\left(0,015^{2} 0,016^{2}\right)+\left(0,016^{2} 0,060^{2}\right)}} \\
& =\frac{255 \times 10^{-6}}{\sqrt{\left(10404 \times 10^{-10}\right)+\left(576 \times 10^{-10}\right)+\left(9216 \times 10^{-10}\right)}} \\
& \sqrt{\left(10.404 \times 10^{-10}\right)+\left(576 \times 10^{-10}\right)+\left(9.216 \times 10^{-10}\right)}
\end{aligned}
$$


$=\frac{255 \times 10^{-6}}{\sqrt{20.196 \times 10^{-10}}}$

$=\frac{255 \times 10^{-6}}{0,00142}=0,1796$

Perhitungan uji sobel menghasilkan nilai t hitung untuk koefisien jalur pengaruh tidak langsung $\left(p_{2} p_{3}\right)$ sebesar 0,1796 . Nilai $t$ tabel untuk $\mathrm{df}=57$ dengan sig. 0,05 adalah sebesar 2,0025 . Nilai t hitung sebesar $0,1796<2,0025$, yang berarti bahwa tidak terdapat pengaruh mediasi atau $\mathrm{H}_{3}$ ditolak, karena kinerja lingkungan tidak dapat menjadi mediator pada hubungan antara akuntansi manajemen lingkungan dengan kinerja keuangan.

Kinerja lingkungan tidak dapat memediasi hubungan antara akuntansi manajemen lingkungan dengan kinerja keuangan, karena adanya kinerja lain atau tindakan lain yang mampu memediasi akuntansi manajemen lingkungan dengan kinerja keuangan, yang tidak diuji lebih lanjut dalam penelitian ini. Kinerja lain dapat berupa kinerja operasional dan kinerja pabrik, sedangkan tindakan lain dapat berupa inisiatif perusahaan dalam melakukan atau mengungkapkan CSR dan pembagian dividen atas sebagian laba yang dihasilkan perusahaan.

Berdasarkan penjelasan di atas, maka hasil penelitian ini tidak mendukung stakeholder theory, karena penerapan akuntansi manajemen lingkungan tidak membantu perusahaan menghasilkan kinerja lingkungan yang baik, sehingga kepentingan masyarakat dan pemerintah tidak dapat terpenuhi. Kinerja lingkungan yang baik juga tidak mampu menciptakan nilai bagi shareholder perusahaan dan tidak berimbas pada kinerja keuangan perusahaan. Hasil penelitian ini konsisten dengan penelitian Rahmadhani dan Meylani (2016), namun inkonsisten dengan penelitian Henri and Journeault (2010).

\section{PENUTUP}

Berdasarkan hasil pengujian dapat diperoleh kesimpulan bahwa penerapan akuntansi manajemen lingkungan tidak berpengaruh terhadap kinerja lingkungan dan kinerja lingkungan tidak berpengaruh terhadap kinerja keuangan. Hasil pengujian juga menunjukkan bahwa kinerja lingkungan tidak dapat menjadi mediator pada hubungan antara akuntansi manajemen lingkungan dengan kinerja keuangan.

Saran untuk peneliti selanjutnya adalah terkait sampel penelitian. Peneliti selanjutnya sangat disarankan untuk menggunakan sektor industri tunggal, sehingga dapat diperoleh hasil yang berbeda dari penelitian ini. Saran untuk perusahaan yang telah berupaya menjaga kelestarian lingkungan melalui penerapan $\mathrm{AML}$ adalah agar perusahaan dapat menghasilkan keputusan bisnis yang lebih baik dalam hal pengelolaan lingkungan dengan memanfaatkan informasi fisik dan moneter yang dihasilkan, sehingga perusahaan mampu mencapai kinerja lingkungan yang diinginkan dan meningkatkan kinerja keuangan perusahaan dalam jangka panjang.

\section{REFERENCES:}

Adharsyah, T. 2019. Sebegini Parah Ternyata Masalah Sampah Plastik di Indonesia. (https://googleweblight.com/i?u=https://www.cnbcindonesia.com/lifestyle/20190721140139-3386420/sebegini-parah-ternyata-masalah-sampah-plastik-di-indonesia\&hl=en-ID, 24 Februari 2020).

Al-Tuwaijri, S. A., Christensen, T. E., \& Ii, K. E. H. 2003. The Relations among Environmental Disclosure, Environmental Performance, and Economic Performance: A Simultaneous Equations Approach, 1-37.

Andayani, R. 2015. Hubungan antara ISO 14001, Environmental Performance dan Environmental Disclosure terhadap Economic Performance. Jurnal Akuntansi Dan Sistem Teknologi Informasi, 11(2), 186-193.

Badan Pusat Statistik. 2018. Statistik Lingkungan Hidup Indonesia 2018. Jakarta. 
Bahri, S., \& Cahyani, F. A. 2016. Pengaruh Kinerja Lingkungan terhadap Corporate Financial Performance dengan Corporate Social Responsibility Disclosure sebagai Variabel Intervening (Studi Empiris pada Perusahaan Manufaktur yang Terdaftar di BEI). Jurnal Ekonomi Universitas Kadiri, 1(2), 117-142.

Burritt, R. L., \& Saka, C. 2006. Environmental Management Accounting Applications and Eco-efficiency: Case Studies from Japan. Journal of Cleaner Production, 14, 1262-1275. https://doi.org/10.1016/j.jclepro.2005.08.012

Evita, M., \& Syafruddin. 2019. Pengaruh Biaya Lingkungan, Kinerja Lingkungan, dan ISO 14001 terhadap Kinerja Keuangan Perusahaan Pertambangan Studi Kasus pada Bursa Efek Indonesia Tahun 2014-2017, 13(1), 28-37.

Fernando, S., \& Lawrence, S. 2014. A Theoretical Framework for CSR Practices: Integrating Legitimacy Theory, Stakeholder Theory and Institutional Theory. The Journal of Theoretical Accounting, 10(1), 149-178.

Freeman, R. E., Harrison, J. S., \& Wicks, A. C. 2007. Managing for Stakeholders: Survival, Reputation, and Success. New Haven \& London: Yale University Press.

Freeman, R. E., Harrison, J. S., Wicks, A. C., Parmar, B. L., \& Colle, S. de. 2010. Stakeholder Theory: The State of The Art. New York: Cambridge University Press. Retrieved from www.cambridge.org/9780521137935

Ghozali, I., \& Chariri, A. 2014. Teori Akuntansi (4th ed.). Semarang: Badan Penerbit Universitas Diponegoro.

Henri, J., \& Journeault, M. 2010. Eco-control: The Influence of Management Control Systems on Environmental and Economic Performance. Accounting, Organizations and Society, 35, 63-80. https://doi.org/10.1016/j.aos.2009.02.001

Herdiyan. (2018). Anugerah Proper 2018, Tingkat Ketaatan Perusahaan terhadap Lingkungan Hidup Makin Meningkat. (https://ekonomi.bisnis.com/read/20181227/257/873293/anugerah-proper-2018-tingkatketaatan-perusahaan-terhadap-lingkungan-hidup-makin-meningkat\#, 05 Maret 2020).

Hidayat, L., \& Salim, S. 2013. Analisis Biaya Produksi dalam Meningkatkan Profitabilitas Perusahaan. Jurnal IImiah Manajemen Kesatuan, 1(2), 159-168.

International Federation of Accountants. International Guidance Document: Environmental Management Accounting 2005. United States of America: International Federation of Accountants.

ISO 14031. Environmental management - Environmental performance evaluation - Guidelines (2013). ISO.

Lankoski, L. 2000. Determinants of Environmental Profit An Analysis of The Firm-Level Relationship Between Environmental Performance and Economic Performance. Helsinki University of Technology.

Latan, H., Jabbour, C. J. C., Jabbour, A. B. L. de S., Wamba, S. F., \& Shahbaz, M. 2018. Effects of Environmental Strategy, Environmental Uncertainty and Top Management's Commitment on Corporate Environmental Performance: The Role of Environmental Management Accounting. Journal of Cleaner Production, 180, 297-306. https://doi.org/10.1016/j.jclepro.2018.01.106

Menteri Lingkungan Hidup dan Kehutanan Republik Indonesia. 2018. Keputusan Menteri Lingkungan Hidup dan Kehutanan Republik Indonesia Nomor SK.613/Menlhk/Setjen/KUM.1/12/2018 tentang Hasil Penilaian Peringkat Kinerja Perusahaan dalam Pengelolaan Lingkungan Hidup Tahun 2017-2018.

Miroshnychenko, I., Barontini, R., \& Testa, F. 2017. Green practices and financial performance: A global outlook. Journal of Cleaner Production, 147, 340-351. https://doi.org/10.1016/j.jclepro.2017.01.058

Phan, T. N., Baird, K., \& Su, S. 2017. The Use and Effectiveness of Environmental Management Accounting. Australasian Journal of Environmental Management, $0(0), \quad 1-20$. https://doi.org/10.1080/14486563.2017.1354235

Phan, T. N., Baird, K., \& Su, S. 2018. Environmental Activity Management: Its Use and Impact on Environmental Performance. Accounting, Auditing \& Accountability Journal, 31(2), 651-673. https://doi.org/10.1108/AAAJ-08-2016-2686

Putra, D., \& Utami, I. L. 2017. Pengaruh Environmental Performance Terhadap Environmental Disclosure dan Economic Performance (Studi Empiris pada Perusahaan Pertambangan yang Terdaftar Di BEI). Jurnal Akuntansi, 9(1), 1-11.

Rahmadhani, S., \& Meylani, D. 2016. Pengaruh Eco-control terhadap CSR Disclosure dan Financial Performance dengan Environmental Performance sebagai Variabel Intervening. Jurnal Dinamika Ekonomi \& Bisnis, 
13(1), 32-46.

Rohmah, I. L., \& Wahyudin, A. 2015. Pengaruh Environmental Performance terhadap Economic Performance dengan Environmental Disclosure sebagai Variabel Intervening (Studi Empiris pada Perusahaan Manufaktor yang terdaftar di Bursa Efek Pada tahun 2010-2012). Accounting Analysis Journal, 4(1), 1 13. Retrieved from http://journal.unnes.ac.id/sju/index.php/aaj

Sambharakreshna, Y. 2009. Akuntansi Lingkungan dan Akuntansi Manajemen Lingkungan: Suatu Komponen Dasar Strategi Bisnis. Jurnal Infestasi, 5(1), 1-21.

Sarumpaet, S. 2005. The Relationship between Environmental Performance and Financial Performance of Indonesian Companies. Jurnal Akuntansi \& Keuangan, 7(2), 89-98. Retrieved from http://www.petra.ac.id/ puslitjournals/dir.php?DepartmentID=AKU

Sawitri, A. P. 2017. Analisis Pengaruh Pengungkapan Akuntansi Lingkungan dan Kinerja Lingkungan terhadap Nilai Perusahaan, 177-187.

Setiawan, W., Budi, L., \& Pranaditya, A. 2018. Pengaruh Kinerja Lingkungan, Biaya Lingkungan dan Ukuran Perusahaan terhadap Kinerja Keuangan dengan Corporate Social Responsibility (CSR) sebagai Variabel Intervening (Studi Kasus Perusahaan pada Perusahaan Manufaktur yang terdaftar di Bursa Efek Indones. Jurnal of Accounting 2018, 1-12.

Sofuroh, F. U. 2019. Pemerintah Targetkan Sampah Plastik di Laut Berkurang 70\% pada 2025. (https://m.detik.com/news/berita/d-4757936/pemerintah-targetkan-sampah-plastik-di-laut-berkurang-70pada-2025, 24 Februari 2020).

Solovida, G. T., \& Latan, H. 2017. Linking environmental strategy to environmental performance : mediation role of environmental management accounting. Sustainability Accounting, Management and Policy Journal. Retrieved from https://doi.org/10.1108/ SAMPJ-08-2016-0046

Supadi, Y. M., \& Sudana, I. P. 2018. Pengaruh Kinerja Lingkungan dan Corporate Social Responsibility Disclosure pada Kinerja Keuangan Perusahaan sektor Pertambangan. E-Jurnal Ekonomi Dan Bisnis Universitas Udayana, 7(4), 1165-1192.

Wang, S., Wang, H., \& Wang, J. 2019. Exploring The Effects of Institutional Pressures on The Implementation of Environmental Management Accounting: Do Top Management Support and Perceived Benefit Work? Wiley Business Strategy and The Environment, 28, 233-243. https://doi.org/10.1002/bse.2252

Wibisono, A. G. 2011. Pengaruh Environmental Performance dan Environmental Disclosure terhadap Economic Performance pada Perusahaan Pertambangan dan Pemegang HPH/HPHTI yang terdaftar di BEl. Universitas Negeri Yogyakarta.

Worldometers.info. 2020. Top 20 Largest Countries by Population. (https://googleweblight.com/i?u=https://www.worldometers.info/world-population/\&hl=en-ID, 08 Februari 2020).

Wulandari, R. D., \& Hidayah, E. 2013. Pengaruh Environmental Performance dan Environmental Disclosure terhadap Economic Performance (Studi pada Perusahaan Manufaktur yang terdaftar di Bursa Efek Indonesia Periode 2009-2011). Jurnal Ekonomi Dan Bisnis Islam2, 7(2), 233-244.

Xiaomei, L. 2004. Theory and Practice of Environmental Management Accounting Experience of Implementation in China. International Journal of Technology Management and Sustainable Development, 3(1), 47-57. https://doi.org/10.1386/ijtm.3.1.47/0 
